\title{
"DZIEDZICTWO BEZ OJCZYZNY”. CERKIEW PRAWOSŁAWNA ŚW. MĘCZENNICY ALEKSANDRY W STANISŁAWOWIE POD MODLINEM W LATACH II RZECZYPOSPOLITEJ I WSPÓłCZEŚNIE
}

\author{
Abstract \\ "HERITAGE WITHOUT A HOME". THE ORTHODOX CHURCH \\ OF SAINT ALEXANDRA THE MARTYR IN STANISLAWOWO NEAR MODLIN \\ IN THE SECOND POLISH REPUBLIC AND TODAY
}

The paper aims to present the history of the Orthodox parish founded on the orders of the Tsarist authorities in the 1930s for the settlers specially brought from Russia to Warsaw. The parish, together with the monumental Orthodox Church of Saint Alexandra the Martyr, flourished until the outbreak of World War I, when the army and the Russian administration were evacuated from the Kingdom of Poland and the Church was destroyed. After Poland had regained its independence, the Church lost its former privileges and started to attract the hostility and unwillingness on the part of the Polish authorities. Despite this, thanks to the efforts of the remaining faithful, the Church was rebuilt (although in a much more modest form), and the faithful were given an Orthodox priest. Today, the Church, being the only rural Orthodox temple in Mazovia, is covered by conservator's protection and is considered a symbol of multiculturalism.

Using the Orthodox Church of Saint Alexandra as an example, the paper is an attempt to illustrate how Poland manages the unwanted, "inconvenient" heritage which over time is integrated into the Polish cultural landscape and becomes devoid of negative evaluation.

The deliberations are based primarily on the archival administrative and parish records kept in the Central Archives of Modern Records (AAN) and on the iconographic materials from the Central Archives of Historical Records (AGAD).

SŁOWA KLUCZE: prawosławie, cerkiew prawosławna, kolonia aleksandryjska, Stanisławowo, Modlin, II Rzeczpospolita, Imperium Rosyjskie, materialne dziedzictwo kulturowe

KEY WORDS: Orthodoxy, Orthodox Church, Alexandria colony, Stanislawowo, Modlin, II Polish Republic, Russian Empire, tangible cultural heritage 
Cerkiew św. Męczennicy Aleksandry w Stanisławowie jest obok cerkwi Świętej Trójcy na Podwalu w Warszawie i soboru Wszystkich Świętych w Piotrkowie Trybunalskim świątynią prawosławną posiadającą najstarszą metrykę na terenach współczesnej centralnej Polski. Jej wyjątkowy charakter podkreśla fakt, że funkcjonuje przy niej jedyna wiejska placówka parafialna na terenie Mazowsza. Choć od powstania obiektu minęło już blisko 170 lat, a w tym czasie był poddawany gruntownym przekształceniom i kilku generalnym remontom, nadal jest świadectwem wydarzeń, które zaistniały w latach trzydziestych i czterdziestych XIX wieku w widłach Wisły, Narwi i Wkry, na okolicznych terenach twierdzy Modlin, Zakroczymia i Nowego Dworu. W tym czasie, zarządzeniem ks. Iwana Paskiewicza, z dużym rozmachem przeprowadzono akcję, która nie miała precedensu na terenie całego Królestwa Polskiego. Na wskazane tereny sprowadzono kilkuset prawosławnych osadników z terenów Imperium Rosyjskiego, którzy z jednej strony mieli stanowić zaplecze dla modernizowanej twierdzy w Modlinie, z drugiej zaś - jak pisał ks. Vasilij Torskij - zjednywać prawosławiu Polaków mieszkających w sąsiednich miejscowościach ${ }^{1}$.

Celem niniejszego artykułu jest ukazanie położenia tej prawosławnej społeczności (potomków pierwszych kolonistów) i ich świątyni w okresie międzywojennym (1918-1939) oraz w realiach współczesnych. Kluczowy dla rozważań dotyczących tych lat będzie rok 1915, w którym działania militarne państw centralnych doprowadziły do całkowitego wyparcia wojsk rosyjskich z terenów Królestwa Polskiego. Wraz z nimi władze carskie podjęły szeroko zakrojoną ewakuację aparatu administracyjnego, prawosławnego duchowieństwa, a także sporej liczby ludności cywilnej, z której część już na te tereny nie powróciła ${ }^{2}$. Zakończenie I wojny światowej przypieczętowało upadek trwającego stulecie rosyjskiego porządku. Dotychczasowy uprzywilejowany status prawosławia spotkał się w II Rzeczypospolitej z postawami dyskryminacji, nieufności i obojętności. Prawosławne świątynie utożsamiano bowiem jednoznacznie z polityką rusyfikacji i represji carskiego zaborcy, wymierzoną w polską ludność i lokalny krajobraz urbanistyczny. W polskim etosie narodowym, opartym m.in. na niepodległościowych zrywach z lat trzydziestych i sześćdziesiątych XIX wieku oraz religii katolickiej, nie przewidywano miejsca dla cerkwi - traktowanych jako ,pomnik i świadectwo najwstrętniejszej tyranji ducha, przez najdziksze instynkty rosyjskie stosowanej względem Polaków"3.

Cerkwi stanisławowskiej, a obok niej dziesiątek innych rosyjskich cerkwi na Mazowszu, nie traktowano w związku z tym w niepodległej Polsce jako dziedzictwa kulturowego, a raczej jako na wskroś „,niewygodną”, „kłopotliwą” i „,wstydliwą” spuściznę zaborów, przy tym porzuconą przez głównego dziedzica, czyli państwo

${ }^{1}$ V. Torskij, Aleksandrinskij pravoslavnyj prihod i hram v russkih koloniâh Varšavskoj gubernii, „Cholmsko-Varšavskì Eparhìal'nyj Vjestnik” (dalej: „CHVEV”), G. XX, n. 15, 1 (13) avgusta 1896, s. 277.

${ }^{2}$ Na ten temat zob. m.in. M. Korzeniowski, M. Mądzik, D. Tarasiuk, Tułaczy los. Uchodźcy polscy w Imperium Rosyjskim w latach pierwszej wojny światowej, Lublin 2007.

3 A. Delnicki, W sprawie cerkwi, „Dziennik Narodowy”, 1.02.1919, R. V, nr 26, s. 4. 
rosyjskie ${ }^{4}$. Do tego wywołującą swoisty dysonans, gdyż była to spuścizna, bądź co bądź, o charakterze sakralnym, związana z kulturą chrześcijańską.

Niezwykle interesujące będzie zatem prześledzenie losów świątyni i grupy wiernych zdecydowanych pozostać na terenie swojej małej ojczyzny, która w odmienionych realiach stała się dla nich obca i wroga. Krótkie spojrzenie na dzisiejszą parafię św. Aleksandry pozwoli natomiast dostrzec, jak przez kolejne dziesięciolecia zmieniła się owa społeczność wiernych, a także, jak ewoluował stosunek polskich władz, które przed blisko stu laty odnosiły się do prawosławnej placówki jednoznacznie negatywnie, z czasem zaś zaczęły traktować ją jako dobro, warte przekazania kolejnym pokoleniom.

W tym kontekście celem artykułu będzie zwrócenie uwagi na problem zarządzania „niewygodnym” dziedzictwem - jak słusznie zauważają Magdalena Banaszkiewicz i Sabina Owsianowska - takim, z którym ogół społeczeństwa się nie identyfikuje, którego wolałby nie dziedziczyć po przodkach i wymazać z pamięci ${ }^{5}$.

Osadnictwu rosyjskiemu oraz rozwojowi prawosławnych placówek parafialnych w regionie poświęcono dotychczas sporą liczbę pozycji badawczych. Największą wartość wśród nich prezentują prace o metryce jeszcze dziewiętnastowiecznej (o charakterze źródłowym), autorstwa Ioana Korżeniewskiego i Vasilija Torskiego, którym opisywane zagadnienia były stosunkowo bliskie ${ }^{6}$. W głównej mierze na ich podstawie swoje rozważania oparli badacze powojenni ${ }^{7}$ oraz współcześni ${ }^{8}$. Obszarem ich zainteresowania była ponadto perspektywa lat międzywojennych i okres po II wojnie światowej. Dodatkowo skupili się oni na kwestii pochodzenia kolonistów oraz, wykorzystując metodę oral history, na sposobach utrwalenia obecności dawnych osadników i ich cerkwi w pamięci współczesnych mieszkańców Stanisławowa i okolic ${ }^{9}$. W żadnej z prac nie omówiono jednak szerzej problematyki prawosławnej

${ }^{4} \mathrm{Na}$ temat różnych przykładów i kontekstów „niewygodnego”, sakralnego dziedzictwa zob. m.in.: E. Kocój, Dziedzictwo bez dziedziców? Religijne i materialne dziedzictwo kulturowe mniejszości pochodzenia woloskiego w Europie w kontekście projektu interdyscyplinarnych badań (przyczynek do tematu), „Zarządzanie w Kulturze” 2015, nr 16, z. 2, s. 137-150; O. Solarz, Bóle fantomowe, czyli o burzeniu cerkwi i sprawiedliwości bożej w Bieszczadach po 1947 r., „Prace Etnograficzne” 2016 , t. 44 , nr 1, s. 25-38.

${ }_{5}$ M. Banaszkiewicz, S. Owsianowska, Trudne dziedzictwo a turystyka. O dysonansie dziedzictwa kulturowego, „Turystyka Kulturowa” 2015, nr 11, s. 13.

${ }^{6}$ A. Lotockij, Cerkovno-istoričeskoe i statičeskoe opisanie Varšavskoj Pravoslavnoj Eparhii. Sostavennoe v 1853 g. Klûčarem Varšavskago kafedral'nago sobora, Počaev 1863, s. 285-286; I. Korženevskij, Kratkaâ istoriâ Cholmsko-Varšavskoj eparhii. Sostoânie varšavskoj eparhii pod upravleniem preosv. Nikanora, „CHVEV”, G. II, n. 22, 15 (27) noâbra 1878, s. 6-14; V. Torskij, Aleksandrinskij pravoslavnyj prihod..., s. 277-279; Tenże, Aleksandrinskij pravoslavnyj prihod i hram v russkih koloniâh Varšavskoj gubernii (Okončanie), „CHVEV”, G. XX, n. 16, 15 (27) avgusta 1896, s. 286-288.

7 R. Kozlovskij, Pravoslavnyj prihod v Stanislavove, „Cerkovnyj Vestnik” maj-iûn 1971, s. $22-24$.

8 P. Rajecki, Parafia św. męczennicy Aleksandry w Stanisławowie koło Pomiechówka, „Kalendarz Prawosławny" 2006, s. 175-182.

9 A. Woźniak, Kartki z dziejów prawosławnej parafii św. Aleksandry w Stanisławowie koło Modlina, „Etnografia Polska” 2001, t. 45, z. 1-2, s. 183-194; K. Sielicka-Baryłka, Ślad estoński na 
społeczności w II Rzeczypospolitej, skupiając się jedynie na podstawowych faktach. Nowe światło na ten okres rzucają akta Ministerstwa Wyznań Religijnych i Oświecenia Publicznego (dalej: MWRiOP) zgromadzone w warszawskim Archiwum Akt Nowych (dalej: AAN), które nie były dotychczas brane przez badaczy pod uwagę. Pozwalają spojrzeć na stanisławowską parafię z perspektywy m.in. wójta gminy Pomiechowo, komendanta twierdzy Modlin, metropolity Dionizego czy wreszcie samych wiernych. Akta te, obok planów i rysunków architektonicznych z Archiwum Głównego Akt Dawnych (dalej: AGAD) obrazujących rozmieszczenie kolonii i pierwotny wygląd cerkwi, będą podstawą treści niniejszego artykułu.

\section{Gosudar Imperator [...] soizvolil okružit' kolcom russkih poselenij (kolonij) i vozdvignut' dlâ nih pravoslavnyj hram}

Decyzję ks. Paskiewicza o sprowadzeniu kolonistów rosyjskich należy rozpatrywać w kontekście reorganizacji carskiej polityki, która nastała w Królestwie Polskim wraz ze stłumieniem powstania listopadowego. Wystąpienia zbrojne, do których doszło w czasie jego trwania, zmobilizowały rosyjskie władze do rozbudowy i modernizacji systemu obronnego na ziemiach polskich, co zaplanowano jeszcze w latach dwudziestych. Powstała wtedy warszawska Cytadela, twierdza w Brześciu i Dęblinie (ros. Ivangorod). W tym czasie zainicjowano również rozbudowę napoleońskiej twierdzy w Modlinie (ros. Novogeorgievsk) ${ }^{10}$. Z jednej strony miały one umocnić zachodnią granicę Imperium Rosyjskiego przed atakiem z zewnątrz, z drugiej - przeciwdziałać kolejnym rozruchom miejscowej ludności. Najpewniej z tymi dwiema przesłankami wiązała się idea rosyjskiego osadnictwa wokół wysuniętych najbardziej na zachód modlińskich umocnień. Akcja rozpoczęła się w II połowie lat trzydziestych na terenach odległych o kilka kilometrów od twierdzy ${ }^{11}$. Najprawdopodobniej pierwsi osadnicy zamieszkali w polskich wsiach, u miejscowych gospodarzy, ponieważ właściwe kolonie założono dopiero w kolejnych latach. Były to Kolonia Aleksandryjska (obecne Stanisławowo), Konstantynowska (obecnie Boża Wola), Zakroczymska, Szczypiorno i Kossewko. Zaplanowano w nich kolejno 25, 12, 7, 20 i 10 zagród. Początkowo miało je zasiedlić 200 mężczyzn i 150 kobiet $^{12}$. Według badań Andrzeja Woźniaka i Klary Sielickiej-Baryłki sprowadzono ich z guberni pskow-

Mazowszu - prawosławna parafia w Stanisławowie, praca magisterska napisana pod kierunkiem dr. hab. J. Wasilewskiego w Instytucie Etnologii i Antropologii Kulturowej Uniwersytetu Warszawskiego, Warszawa 2003. (Ustalenia, na które będę się powoływał, pochodzą z kopii pracy udostępnionej mi przez p. K. Sielicką-Baryłkę. W tym miejscu chciałbym serdecznie podziękować za to Autorce).

10 P. Paszkiewicz, Pod berłem Romanowów. Sztuka rosyjska w Warszawie 1815-1915, Warszawa 1991, s. 18-19.

${ }^{11}$ Początkowo planowano, aby kolonie powstały w bliskiej odległości od modlińskiej twierdzy. Obrazuje to zachowany plan ich rozmieszczenia: AGAD, Zbiór kartograficzny (dalej: Zk), sygn. 199-19, Plan der neuangelegten Colonie bei Modlin im Amte Zakroczym copirt durch Linke, b.d.

${ }_{12}$ V. Torskij, Aleksandrinskij pravoslavnyj prihod..., s. 277-278. 
skiej, z terenów dzisiejszego pogranicza estońsko-rosyjskiego i należeli oni do etnograficznej grupy Setu. Nie były to zatem, jak chciał V. Torskij, Vielkorusy, a ludność pochodzenia estońskiego ${ }^{13}$.

Na podstawie zachowanego planu Kolonii Aleksandryjskiej, sygnowanego datą 21 września (3 października) 1840 roku i nazwiskiem budowniczego Schülza można wskazać, jak pierwotnie przedstawiał się plan przestrzenny miejscowości, widoczny do dziś w układzie komunikacyjnym. Gospodarstwa kolonistów zaplanowano po wschodniej stronie drogi, którą wytyczono równolegle do trasy z Nowego Dworu do Serocka. Areał między obiema drogami przeznaczono natomiast na pola uprawne. Każdy z domów był zwrócony szczytem do ulicy i składał się z dwóch izb rozdzielonych korytarzem (być może dla dwóch rodzin). Na granicy sąsiadujących z sobą gospodarstw przewidziano budynki gospodarcze: stajnię, oborę i szopę, a na wschód od nich, w niewielkiej odległości, dwie ustawione obok siebie stodoły. W centrum miejscowości zaplanowano dwie większe zagrody na planie podkowy, gdzie poza wymienionymi obiektami znalazły się jeszcze domy targowe ${ }^{14}$.

Wszystkie zagrody, w „,czysto rosyjskim stylu”, z drewnianych bali, mieli wznieść cieśle specjalnie do tego celu sprowadzeni z Rosji ${ }^{15}$. Wyposażono je m.in. w sprzęty domowe, narzędzia rolnicze oraz żywność do czasu zebrania pierwszych plonów. Na okres sześciu lat koloniści oraz ich dzieci otrzymali zwolnienie z pełnienia służby wojskowej. Dodatkowo każda rodzina została uposażona w 20 morgów ziemi $^{16}$.

Kolonie przypisano do parafii funkcjonującej na terenie twierdzy w Modlinie. Tamtejsza cerkiew, poświęcona św. Jerzemu, powstała w latach 1835-1836 i wkrótce podniesiono ją do rangi soboru. Świątynie dla żołnierzy rosyjskich pobudowano w podobnych latach również w Warszawie (św. Aleksandra Newskiego), w Dęblinie (św. Jana Chrzciciela) ${ }^{17}$. Osadnicy jednak, jak podawał I. Korženevskij, nie widzieli potrzeby uczestniczenia w liturgii, jak też nie praktykowali żadnych obrzędów religijnych ${ }^{18}$. K. Sielicka-Baryłka na podstawie pochodzenia osadników tłumaczy, że taka postawa mogła być spowodowana ich stosunkowo niedawnym przejściem na prawosławie $\mathrm{z}$ luteranizmu lub $\mathrm{z}$ wierzeń związanych $\mathrm{z}$ bóstwami przyrody ${ }^{19}$. Wśród części osadników należałoby upatrywać również staroobrzędowców ${ }^{20}$ (il. 1).

13 A. Woźniak, Kartki z dziejów..., s. 188; K. Sielicka-Baryłka, Ślad estoński..., s. 8-11.

${ }^{14}$ AGAD, Zk, sygn. 324-101, Plan sytuacyjny Kolonii Aleksandryjskiej, 1840.

15 A. Szczerbatow, Rządy księcia Paskiewicza w Królestwie Polskim (1832-1847), Warszawa 1900 , s. 139.

${ }^{16}$ V. Torskij, Aleksandrinskij pravoslavnyj prihod..., s. 278; A. Woźniak, Kartki z dziejów..., s. 186.

${ }_{17}$ P. Paszkiewicz, W stużbie Imperium Rosyjskiego 1721-1917. Funkcje i treści ideowe rosyjskiej architektury sakralnej na zachodnich rubieżach Cesarstwa i poza jego granicami, Warszawa 1999, s. 79, 80; P. Cynalewska-Kuczma, Architektura cerkiewna Królestwa Polskiego narzędziem integracji z Imperium Rosyjskim, Poznań 2004, s. 57-59.

${ }^{18}$ I. Korženevskij, Kratkaâ istoriâ..., s. 12.

${ }^{19}$ K. Sielicka-Baryłka, Ślad estoński..., s. 14.

${ }^{20} \mathrm{~V}$. Torskij, Aleksandrinskij pravoslavnyj prihod..., s. 278. 


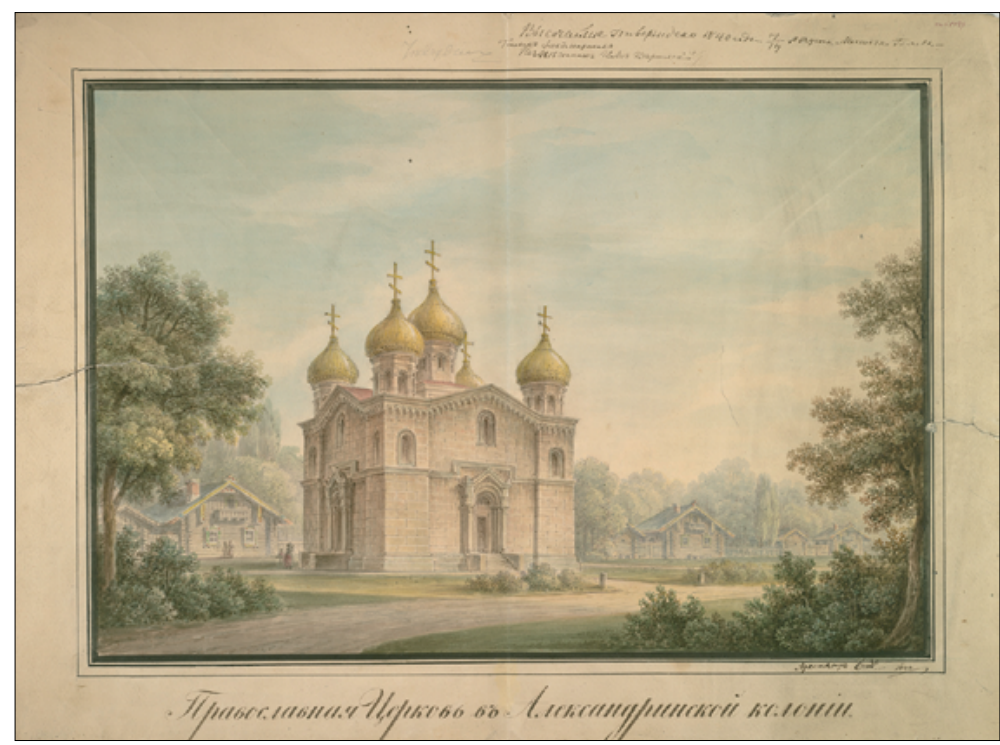

II. 1. Niezrealizowany projekt cerkwi w Kolonii Aleksandryjskiej autorstwa Jana Jakuba Gaya. W tle drewniane zabudowania mieszkalne i gospodarcze rosyjskich kolonistów, 1840. AGAD, Zbiór kartograficzny, sygn. 334-71

Owe czynniki spowodowały, że już w roku 1840 architekt Jan Jakub Gay na zarządzenie władz wykonał projekt cerkwi, która swym zasięgiem miała objąć wszystkie rosyjskie kolonie ${ }^{21}$. Docelowo pod budowę wybrano plac w Kolonii Aleksandryjskiej, jednak nim przyszło do rozpoczęcia prac minęły kolejne cztery lata. O późniejszej metryce cerkwi względem zabudowań w kolonii świadczyło jej usytuowanie. Wzniesiono ją bowiem po wschodniej stronie drogi przecinającej miejscowość, kiedy wszystkie zabudowania znalazły się na zachód od niej. Cerkwi nie umieszczono również na wskazanym wyżej planie Kolonii Aleksandryjskiej, który wykonano w tym samym roku co projekt świątyni.

Być może tak długi okres zwłoki był spowodowany dyskusją nad realizacją koncepcji Gaya, którą ostatecznie w znacznym stopniu zmieniono. Większym przekształceniom nie podlegał centralny plan świątyni, podkreślenie naroży przez ich nieznaczne wysunięcie przed lico muru (na zasadzie psudoryzalitów czy quasi-alkierzy) oraz podziały zastosowane $\mathrm{w}$ elewacjach. Zarówno pierwszy, jak i drugi projekt przewidywał także wykorzystanie motywu pâtiglavâ, czyli przekrycia bryły przez pięć kopuł lub hełmów. Elementy te zostały jednak ukształtowane w odmienny sposób. O ile pierwsza wersja zakładała cebulaste hełmy nasadzone na smukłe latarnie, o tyle w drugiej latarnie zostały przekształcone w masywne i ciężkie ośmioboczne „kondygnacje" psudoryzalitów, a hełmy stały się bardziej kubiczne. Nad partią centralną umieszczono zaś większa kopułę posadowioną bezpośrednio na murze, wieńcząc ją

${ }^{21}$ AGAD, Zk, sygn. 334-71, Pravoslavnaâ Cerkov v Aleksandrinskoj kolonii, 1840. 
dodatkowo bizantyzującym hełmem. Można domniemywać, że przeprowadzona monumentalizacja, przy wykorzystaniu środków stylistycznych odwołujących się do architektury obronnej, miała na celu wizualne dookreślenie misji wyznaczonej kolonistom $^{22}$. W taki sposób interpretowały ją polskie władze w okresie międzywojennym, co wyrażała chociażby opinia Ministerstwa Robót Publicznych w 1930 roku:

Cerkiew ta w celu propagandy prawosławia została pobudowana przez b. zaborców na najwyższem wzniesieniu okolicy, tuż przy jednej z ważniejszych magistrali kolejowych, łączących Warszawę z Gdańskiem $[\ldots]^{23}$.

Wydaje się zatem, że świątynia z jednej strony miała bronić kolonistów przed wpływem polskości i katolickiego wyznania, z drugiej, przez monumentalizm i dogodne pod względem ekspozycji położenie, oddziaływać na innowierców i pozyskiwać ich dla prawosławia. Zastosowanie w dekoracji elewacji fryzu arkadkowego, kolumienek $\mathrm{w}$ ościeżach otworów okiennych czy blend o wykroju prostokąta zamkniętego półkoliście przeprutych okolusami (absyda) służyło zapewne nawiązaniu do świątyń starochrześcijańskich czy wzorców cerkwi staroruskich. Taki zestaw form, przez odniesienie do gmachu spichlerza zbożowego w twierdzy w Modlinie (1832-1844), wskazywałby na Gaya jako twórcę ostatecznej wizji cerkwi św. Aleksandry. Wpisywałby ją również w kontekst architektury użyteczności publicznej końca XVIII i początku XIX wieku ${ }^{24}$ (il. 2).

Znaczenie aleksandryjskiej świątyni podkreślał fakt, że była to jedna z pierwszych cerkwi prawosławnych na terenie Królestwa Polskiego, którą wzniesiono od podstaw i która służyć miała ludności cywilnej ${ }^{25}$. Obok świątyni, po jej wschodniej stronie, powstała murowana dzwonnica o podobnej stylistyce co cerkiew św. Aleksandry, którą również przekryto kopułą. Do domów kolonistów nawiązywały natomiast obiekty parafialne dla prawosławnego duchowieństwa, wzniesione po południowej stronie świątyni (dom mieszkalny i niewielki budynek gospodarczy) ${ }^{26}$.

Pewien sposób zależności kolonii rosyjskich od twierdzy w Modlinie został wyrażony w usytuowaniu parafialnego cmentarza. Założono go na południe od Kolonii Aleksandryjskiej, tuż obok dużo większej nekropolii wojskowej (łącznie 13 morg), na której grzebano zmarłych żołnierzy z Modlina i garnizonu w Kazuniu Nowym. Obie części cmentarza otoczone były wspólnym ogrodzeniem (początkowo drewnianym płotem, a później murem). W roku 1852 w jego południowo-zachodniej części

22 O owej misji świadczyły poza środkami stylistycznymi rozmiary cerkwi - zajmowała ona $640 \mathrm{~m}^{2}$ (bok o długości ok. $25 \mathrm{~m}$ ). Jak na przeznaczenie dla wiejskiej społeczności były to niezwykle duże rozmiary.

${ }^{23}$ AAN, MWRiOP, sygn. 1208, s. 75.

${ }^{24}$ Widok cerkwi zob.: P. Rajecki, Parafia św. męczennicy..., s. 176, 178; K. Sokoł, A. Sosna, Cerkwie w centralnej Polsce 1815-1915, Białystok 2011, s. 127.

${ }^{25} \mathrm{~W}$ latach poprzedzających budowę cerkwi św. Aleksandry na potrzeby kultu prawosławnego przebudowywano przede wszystkim nieczynne kościoły katolickie (wyjątkiem m.in. sobór w Suwałkach). Z czasów I Rzeczypospolitej (końca XVIII w.) pochodziły cerkwie greckie, m.in. w Piotrkowie, Opatowie, Kaliszu czy Warszawie. P. Paszkiewicz, W stużbie Imperium..., s. 67, 79-83.

${ }^{26}$ AAN, MWRiOP, sygn. 1208, s. 118. 
wyświęcono również niewielką murowaną cerkiew Bogurodzicy Pocieszycielki Strapionych ${ }^{27}$. Źródła potwierdzają także istnienie na cmentarzu murowanej stróżówki ${ }^{28}$. Nie zachowały się jednak żadne przekazy ikonograficzne, które pozwoliłyby bliżej określić wygląd tych obiektów.

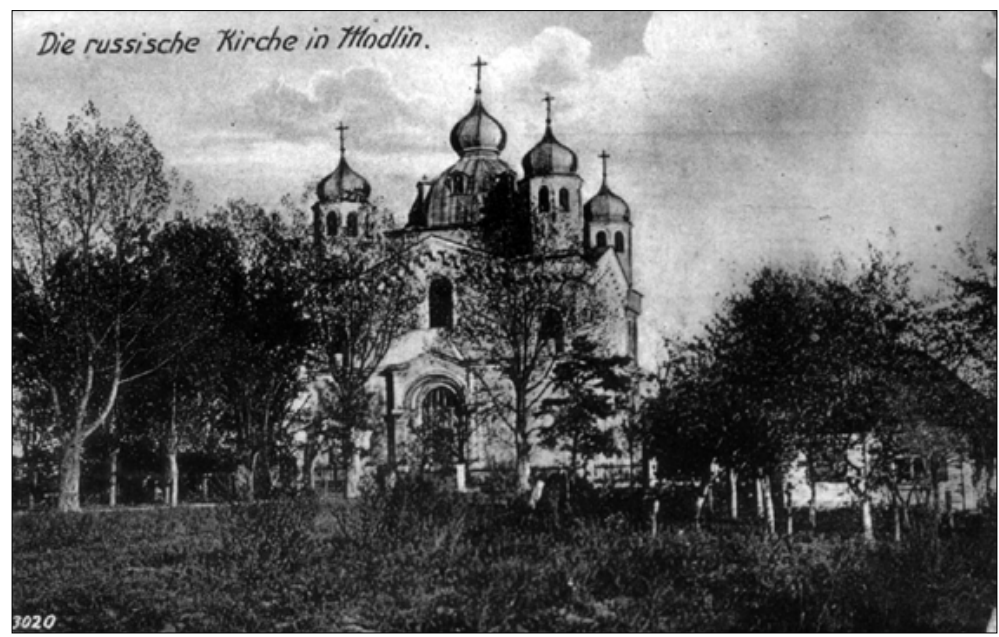

II. 2. Pocztówka z widokiem cerkwi św. Aleksandry w Stanisławowie, XIX/XX w. Zbiory Aleksandra Sosny

Mimo takiego uprzywilejowania kolonistów, duża część z nich nie poradziła sobie w nowych warunkach. Odmienny klimat, odmienne sposoby gospodarowania (rolnictwo, gdy w guberni pskowskiej przede wszystkim rybołówstwo) wymogły decyzję o sprzedaży majątku i powrocie. Chęć aklimatyzacji tych, którzy zdecydowali się osią́śc na stałe, skutkowała natomiast kontaktami z polską ludnością - jej językiem, zwyczajami oraz sposobem bycia. Polacy lub Żydzi przejmowali też opuszczone gospodarstwa. Wszystko to groziło klęską misji, którą powierzono kolonistom. Jak pisał Aleksander Szczerbatow: „W ogólności ludność rosyjska pod Zakroczymem utraciła swą narodowość, a żadnego nie wywarła wpływu na sąsiadujących z nią włościan polskich" ${ }^{29}$. Ten negatywny trend został zahamowany jednak w 1875 roku, gdy Komitet do spraw Królestwa Polskiego w Petersburgu zadecydował, że w rosyjskich koloniach dobra mogą dzierżawić i nabywać wyłącznie prawosławni. Zmianę tę dobrze obrazuje wzrost demograficzny kolonistów: w roku 1874 miały to być 673 osoby, a w 1894 - już 1056. Stopniowo rozrastała się też parafia św. Alek-

${ }^{27}$ A. Lotockij, Cerkovno-istoričeskoe..., s. 285-286; R. Gołąb, Ilustrowana monografia..., s. 441-443.

${ }^{28}$ AAN, MWRiOP, sygn. 1208, s. 5-6.

29 A. Szczerbatow, Rządy księcia..., s. 139-140. 
sandry - objęła swym zasięgiem prawosławnych osiadłych w Wymysłach, Kosewie, Gałachach czy Nowym Dworze ${ }^{30}$. W 1907 roku przyłączono do niej również powiat warszawski i płoński ${ }^{31}$.

\section{„Dzieci pozostają niechrzczone [...], a starsi grzebani bez obrządku chrześcijańskiego"}

Działania militarne I wojny światowej w zdecydowany sposób odbiły się na funkcjonowaniu parafii św. Aleksandry. Należy przypuszczać, że jeszcze przed przesunięciem linii frontu na wysokość Nowego Dworu ewakuował się wraz z pewną liczbą wiernych proboszcz Mikołaj Karpowicz. Z kolei podczas ofensywy Niemców na twierdzę w Modlinie, w sierpniu 1915 roku, znacząco ucierpiała cerkiew ${ }^{32}$. Na podstawie zachowanej ikonografii można stwierdzić, że zniszczeniu uległy: „wieżyczka" wraz z hełmem nad północno-zachodnim narożnikiem świątyni, sklepienie apsydy, a być może również częściowo kopuła i dzwonnica. Do partii ołtarzowej wpadł ponadto pocisk artyleryjski, który ostatecznie nie uległ detonacji ${ }^{33}$. Według relacji świadków łączne straty były jednak tak duże, że świątynia nie nadawała się do dalszego użytku i zdecydowano o jej zamknięciu. Najpewniej w związku z zagrożeniem zawalenia sklepień nie zabezpieczono nawet utensylii liturgicznych i wyposażenia cerkwi, pozostawiając je we wnętrzu obiektu ${ }^{34}$ (il. 3).

Kolejne informacje na temat parafii pochodzą już z czasów niepodległej Polski. W połowie lutego 1919 roku mieszkaniec Szczypiorna, Wiktor Czyczagow, w imieniu kolonistów zwrócił się do komendanta twierdzy w Modlinie płk. Edwarda Malewicza:

Cerkwie prawosławne są zniszczone, a ocalona niewielka cerkiew cmentarna i sam cmentarz prawosławny ograbia nielitościwie, po wyjściu Niemców, ludność okoliczna. Na oczach prawosławnych ołtarz i obrazy kościelne są zniszczone lub porozbijane przez okolicznych mieszkańców, którzy i w czasie obecnym wynoszą oddzielnemi deskami niszczoną cerkiew, dach jej jest zdjęty, ramy okienne, drzwi i podłoga rozebrane i wywiezione. Krzyże drewniane z grobów i żelazne sztachety wywiezione, drogie pomniki i kamienne ogrodzenie cmentarza rozwalone i porozbierane, dom murowany dla Stróży zniszczony, drzewka owocowe wykopane, podobnież drzewa na cmentarzu systematycznie wyrąbywane i wywożone ${ }^{35}$.

Wierni domagali się od władz wojskowych ukrócenia profanacji cmentarnej kaplicy i pochówków oraz ukarania winnych. Na wniosek MWRiOP policja przeprowadziła dochodzenie, które potwierdziło zachowania miejscowej, nieprawosławnej

\footnotetext{
${ }^{30}$ AAN, MWRiOP, sygn. 1208, s. 25.

${ }^{31}$ R. Kozlovskij, Pravoslavnyj prihod..., s. 23.

32 Tamże, s. 23; R. Gołąb, Ilustrowana monografia..., s. 273-274.

33 P. Rajecki, Parafia św. męczennicy..., s. 178-179.

${ }^{34}$ AAN, MWRiOP, sygn. 1208, s. 67.

35 Tamże, s. 5-6.
} 
ludności. Mimo jednak podjęcia środków zaradczych przez władze i wynajęcia przez parafian stróża cmentarnego, wskazanych działań, być może ze względu na znaczące rozmiary nekropolii, nie udało się zahamować3 ${ }^{36}$.

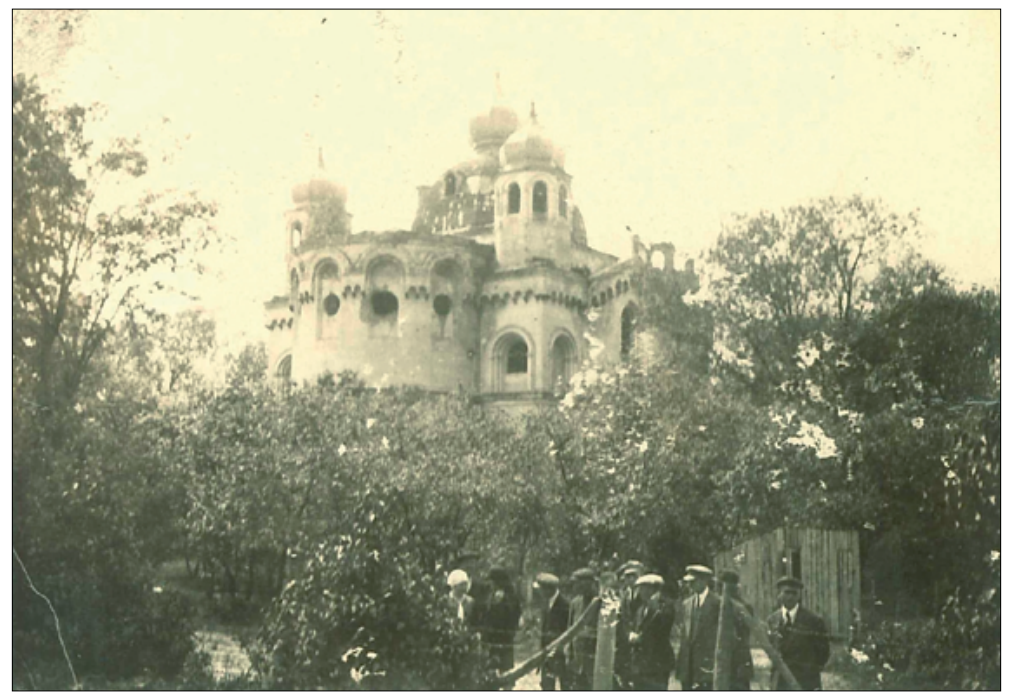

II. 3. Zniszczona cerkiew św. Aleksandry, widok od strony południowo-wschodniej, najpewniej lata dwudzieste XX w. AAN, MWRiOP, sygn. 1208, s. 69. Reprodukcja AAN

Prawosławni uskarżali się także na brak opieki duszpasterskiej, bez której pozostawali od czasu opuszczenia parafii przez ks. Karpowicza. Pogrzeby odbywały się bez chrześcijańskiego obrządku, a w celu ochrzczenia dzieci należało udać się do odległej o blisko $40 \mathrm{~km}$ Warszawy. Czyczagow w kolejnym liście twierdził, że duchowny był niezbędny do prowadzenia akt stanu cywilnego, a także w celu ,zapobieżenia dalszemu zdziczeniu naszej młodzieży i walki z ideałami bolszewizmu w naszym rejonie fortecznym" ${ }^{37}$. Stawiając władze przed faktem dokonanym, wierni wybrali na proboszcza ks. Aleksandra Bogaczowa, który powrócił z Kresów Wschodnich po zakończeniu wojny, i prosili o jego nominację.

Ulokowanie duchownego w Stanisławowie, w związku z ówczesnym przeznaczeniem zabudowań parafialnych, było jednak bardzo utrudnione. Połowę dawnej plebanii użytkowali prywatni właściciele (najpewniej nieprawosławni). Podobnie stało się z sąsiednią stróżówką oraz ziemią rolną, która do I wojny światowej stanowiła uposażenie duchownego. Było to dwanaście morg pól ornych, pięć morg łąki oraz niewielki sad tuż przy cerkwi św. Aleksandry. Część z tych gruntów przekazała parafii wraz z prawami własności osoba prywatna ${ }^{38}$.

\footnotetext{
36 Tamże, s. 18, 19.

37 Tamże, s. 21.

38 Tamże, s. 60-64, 117-118.
} 


\section{Ustawowe uregulowanie stosunku Kościoła do Państwa}

Odebranie ziemi cerkiewnej oraz zabudowań parafii prawosławnej nie miało, jak by się mogło wydawać, charakteru samowolnego. Nowi właściciele dzierżawili je na podstawie umowy z Urzędem Wojewódzkim w Warszawie. Podobny status posiadały cerkiew św. Aleksandry oraz cmentarz w Nowym Modlinie i tamtejsza kaplica Bogurodzicy Pocieszycielki Strapionych. We wszystkich tych przypadkach władze państwowe stawiały siebie w roli zarządcy i właściciela prawosławnego majątku.

W świetle dekretu Namiestnika Państwa Józefa Piłsudskiego z grudnia 1918 roku, a później m.in. traktatu w Rydze kończącego wojnę z bolszewikami, takie organy, jak MWRiOP, Ministerstwo Spraw Wojskowych, Ministerstwo Robót Publicznych, a później także Ministerstwo Rolnictwa i Dóbr Państwowych obdarzono kompetencjami potrzebnymi do decydowania o dalszym losie nieruchomości i ziemi cerkiewnej. Uznano bowiem - jak się później okazało niezgodne z prawdą - że do I wojny światowej parafie prawosławne nie posiadały osobowości prawnej, a w związku z tym nie mogły występować jako właściciel jakichkolwiek dóbr ${ }^{39}$. Skoro zatem cały majątek prawosławny należał formalnie do skarbu państwa rosyjskiego, to po roku 1918 stwierdzono, że jego przejemcą stały się władze państwa polskiego. Podobnie rzecz miała się z wszelkimi gmachami państwowymi czy siedzibami urzędów.

Od chwili odzyskania niepodległości, ze względu na rosyjską hierarchię Kościoła prawosławnego oraz tożsamość narodową wiernych (w większości Rusinów - Ukraińców, ale też Rosjan), dążono do rozciągnięcia nad nimi jak największej kontroli państwowej. Temu służyły starania o uzyskanie autokefalii (zakończone sukcesem w 1925 roku), a tym samym odcięcie od patriarchatu moskiewskiego. Taki sam cel miała ścisła kontrola życia wewnętrznego Cerkwi, m.in. zatwierdzanie na stanowiska duszpasterskie tylko tych duchownych, których lojalny stosunek do Rzeczypospolitej nie podlegał dyskusji, szerzących wśród wiernych lojalne postawy obywatelskie. To od władz państwowych zależało również, w których miejscowościach ustanowione zostaną parafie (przedwojenna sieć przestała istnieć), w jaki sposób zostaną uposażone i jaka liczba duchowieństwa zostanie wyznaczona do ich obsługi. Kluczowe znaczenie miała $\mathrm{w}$ tym zakresie liczba wiernych na terenie projektowanych placówek, która musiała być porównywalna do tej występującej w parafiach katolickich. Warunek ten okazał niemożliwy do spełnienia szczególnie tam, gdzie wśród przedwojennych wiernych dominowali wojskowi czy urzędnicy rosyjscy, ewakuowani w 1915 roku. Stawiało to pod znakiem zapytania dalsze istnienie nie tylko świątyń, ale też innych zabudowań parafii, a także cmentarzy. Sprawę komplikował fakt, że dopiero pod koniec lat trzydziestych pojawiło się ustawodawstwo, w którym podjęto

${ }^{39}$ M. Papierzyńska-Turek, Między tradycją a rzeczywistością. Państwo wobec prawosławia 1918-1939, Warszawa 1989, s. 325-326. 
się regulacji wskazanych kwestii ${ }^{40}$. W ogromnej mierze wpływało to na wydłużenie procesu decyzyjnego odnośnie do takich spraw, jak remont, budowa czy rozbiórka świątyni. W sposób obrazowy ukazują to losy cerkwi św. Męczennicy Aleksandry.

\section{„Prawosławni [...] są elementem spokojnym, lojalnie usposobionym”}

Mimo spadku liczby parafian o przeszło połowę w stosunku do stanu z pierwszego dziesięciolecia XX wieku, stanowili oni w dalszym ciągu znaczącą społeczność. Według danych zebranych przez władze państwowe, w roku 1919 na terenie gminy Pomiechowo miało zamieszkiwać 392 prawosławnych, a na terenie sąsiedniej gminy Góra około $50^{41}$. W kolejnych latach liczby te ulegały znacznym wahaniom, odpowiednio: 397 i 91 w 1921 roku $^{42}, 700$ osób w 1927 (teren dawnej parafii) ${ }^{43}$, 419 i 137 w 1928 ${ }^{44}, 223$ prawosławnych na terenie Stanisławowa i 404 w okolicach w $1932 \mathrm{roku}^{45}$. Niezależnie od dokładności wskazanych informacji należy stwierdzić, że liczby te mogły stanowić podstawę utworzenia placówki parafialnej. Porównywalna liczba wiernych występowała bowiem w parafii Wszystkich Świętych w Piotrkowie, którą MWRiOP powołało dekretem z 11 października 1920 roku $^{46}$. Na takie kroki nie zdecydowano się jednak w Stanisławowie, mimo że zabiegali o to m.in. wójt gminy Pomiechowo oraz starosta powiatu warszawskiego ${ }^{47}$.

Władze ministerialne twierdziły, że rosyjskie kolonie leżą zbyt blisko parafii katedralnej św. Marii Magdaleny w Warszawie, do której zostały przyłączone (księża mieli dojeżdżać do Stanisławowa i na miejscu odprawiać nabożeństwa). Choć organa policji zapewniały, że prawosławni są „elementem spokojnym, lojalnie usposobionym do państwowości polskiej i stosunek ich do władz w ogóle, a do policji w szczególności, jest bez zarzutu"48 - najpewniej właśnie o ich lojalność się obawiano (większość z nich uważała siebie za Rosjan ${ }^{49}$ ). Likwidacja dotychczas istniejącej parafii wiązała się też z realną korzyścią finansową dla państwa - funduszami z dzierżawy ziemi cerkiewnej, a także części plebanii i znajdującej się przy niej stróżówki, przejętych przez prywatnych właścicieli (il. 4).

${ }^{40}$ P. Zubowski, Cerkwie prawosławne Łodzi i regionu łódzkiego w dwudziestoleciu międzywojennym (1918-1939), Białystok 2014, s. 26-28.

${ }^{41}$ AAN, MWRiOP, sygn. 1208, s. 15-16.

${ }^{42}$ A. Woźniak, Kartki z dziejów..., s. 191.

${ }^{43}$ AAN, MWRiOP, sygn.1208, s. 118.

${ }^{44}$ A. Woźniak, Kartki z dziejów..., s. 191.

${ }^{45}$ AAN, MWRiOP, sygn. 1208, s. 117.

46 Tamże, sygn. 1060, s. 121.

47 Tamże, sygn. 1208, s. 52-62.

48 Tamże, s. 62.

49 A. Woźniak, Kartki z dziejów..., s. 191. 


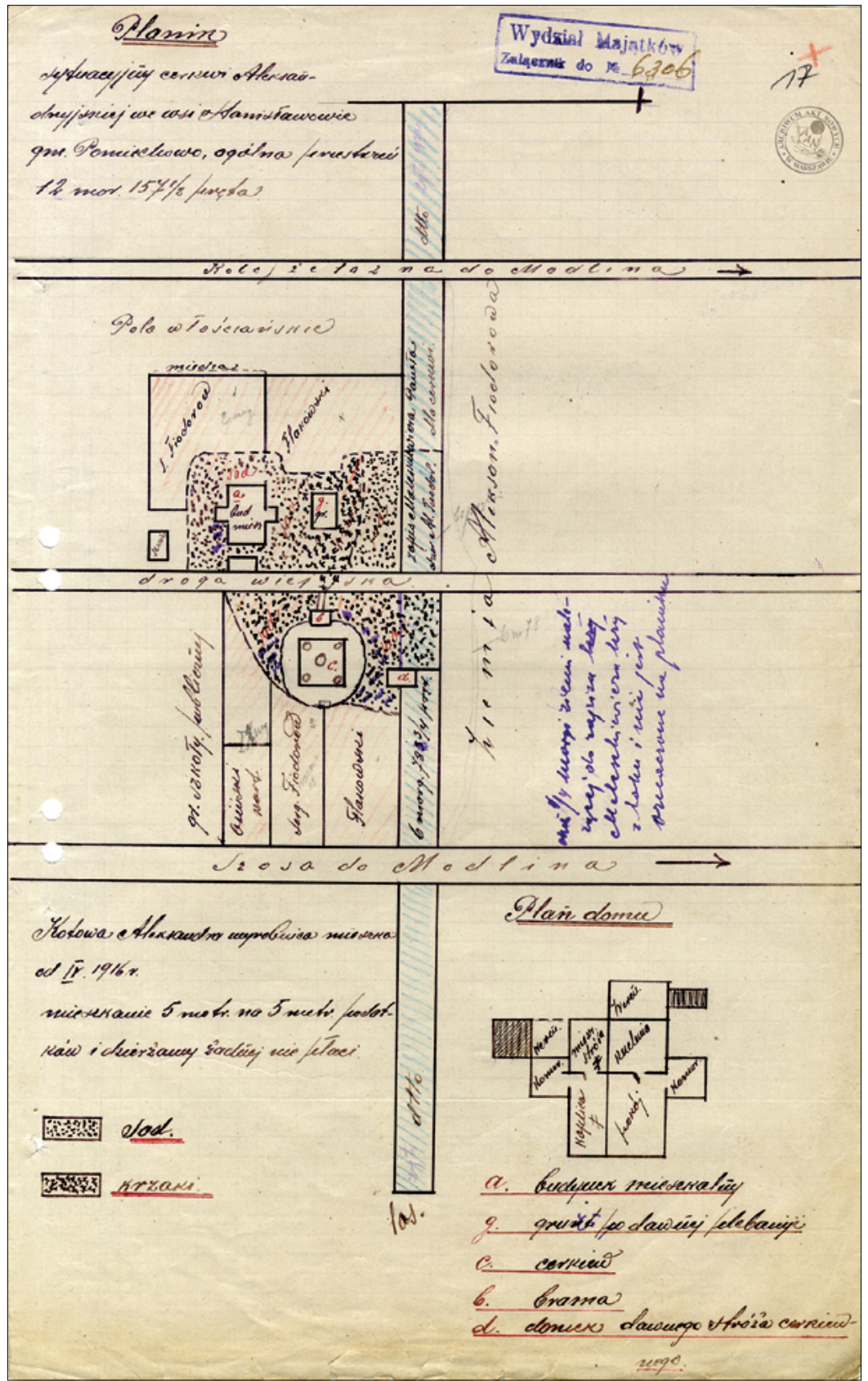

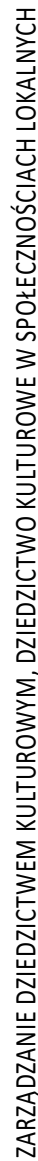

II. 4. Planik sytuacyjny cerkwi Aleksandryjskiej we wsi Stanisławowie, gm. Pomiechowo. Niżej rzut plebanii, której jedno z pomieszczeń przeznaczono w okresie międzywojennym na prawosławną kaplicę. AAN, Ministerstwo Rolnictwa i Reform Rolnych, sygn. 250, s. 17. Reprodukcja AAN 
Ze Stanisławowa odwołano księdza Aleksandra Bogaczowa, którego wierni wybrali na proboszcza ${ }^{50}$. Duże trudności wystąpiły natomiast $\mathrm{z}$ organizacją pomieszczenia, w którym liturgię mogliby sprawować księża dojeżdżający z Warszawy. Cerkiew św. Aleksandry zamknięto, a kaplica cmentarna, do której planowano przenieść nabożeństwa, w dalszym ciągu podlegała dewastacji. Pod koniec września 1919 roku wierni starali się o zgodę na jej odnowienie, pisząc, że „obecnie nie ma dachu, okien, podłogi, pieców, drzwi, a ozdoby zewnętrzne są wszystkie zrabowane" ${ }^{51}$. Najpewniej jednak i tu spotkali się z odmową, bo już w grudniu na skromną kaplicę zaadaptowali jedno z pomieszczeń dawnego domu parafialnego. Choć starostwo powiatowe w Warszawie twierdziło, że „po dokonaniu remontu [cerkiew - dop. P.Z.] będzie mogła w zupełności służyć dla celów religijnych" ${ }^{52}$, należy zaznaczyć, że były to warunki niezwykle trudne. Świątynię ulokowano tylko w jednym z sześciu pomieszczeń parterowego obiektu - jedno przeznaczono na zakrystię, w dwóch mieszkała dozorczyni cerkwi o nazwisku Potapowa, a w kolejnych dwóch prywatny gospodarz. Trudno sobie wyobrazić, jak na tak małej przestrzeni (nawet gdy weźmie się pod uwagę fakt, że nie wszyscy określający siebie jako prawosławni uczestniczyli w nabożeństwach) mogło się pomieścić kilkaset osób. W takich warunkach problematyczne było również zapewnienie noclegu duchownym dojeżdżającym z Warszawy. Z pewnością powadze liturgii nie sprzyjało także ścisłe sąsiedztwo cerkwi z pomieszczeniami zajmowanymi przez nieprawosławnych (zarówno na plebanii, jak i w dawnej stróżówce). Do tego władze powiatowe po kolejnej inspekcji budynku kilka lat później, stwierdziły, że nie nadaje się on do użytku i powinien zostać rozebrany:

Większy dom drewniany, budowany z okrąglaków na wysokiej podmurówce, uległ zniszczeniu, ściany drewniane zmurszałe i stoczone przez robactwo drzewne na wskroś, szczytów brak, pokrycie zniszczone i przeciekające, schodki drewniane zniszczone ${ }^{53}$.

\section{„[...] kwestia utworzenia w Stanisławowie etatowej filji i przydzielenia jej odpowiedniej ilości gruntów"}

20 czerwca 1930 roku MWRiOP, po jedenastu latach starań parafian, zabiegach metropolity Dionizego i pozytywnych opiniach władz samorządowych, wyraziło wreszcie zgodę na przydzielenie do Stanisławowa duchownego i utworzenie placówki parafialnej. Upragniona decyzja nie szła jednak w parze ze zrozumieniem potrzeb wiernych. Władze ministerialne uzależniały ją od zapewnienia przez miejscowych

${ }^{50}$ Wiadomo, że A. Bogaczow od 1928 r. był dziekanem na terenie Dowództwa Okręgu Korpusu nr VII w Poznaniu, a później proboszczem parafii prawosławnej w Poznaniu. Zob. G. Sosna, A. Troc-Sosna, Hierarchia i kler Kościoła prawosławnego w granicach II Rzeczypospolitej i Polski powojennej w XIX-XXI wieku, Ryboły 2012, s. 122.

${ }^{51}$ AAN, MWRiOP, sygn. 1208, s. 26.

52 Tamże, s. 25.

53 Tamże, s. 118. 
zarówno mieszkania dla księdza, jak i jego utrzymania. Kryteria te, w kontekście zrujnowanej plebanii i odebranej ziemi cerkiewnej, nie były możliwe do spełnienia. Swojej pomocy, ze względu na brak funduszy, nie mogła zapewnić również metropolia prawosławna w Warszawie. Mimo to, jak twierdzi Grzegorz Sosna, ksiądz Jan Sajczuk od października 1932 roku zaczął sprawować obowiązki proboszcza parafii św. Męczennicy Aleksandry ${ }^{54}$.

\section{„[...] własnemi środkami pragniemy cerkiew wybudować, na Chwałę Bogu i Ojczyźnie - Polsce"}

Wydaje się, że jedynym wyjściem z trudnej sytuacji finansowej parafii była rozbiórka zniszczonej cerkwi św. Aleksandry i wybudowanie z uzyskanych materiałów mniejszej świątyni i domu parafialnego. Taką propozycję jeszcze w sierpniu 1922 roku przedstawił metropolita Jerzy ${ }^{55}$. W późniejszych latach podnosili ją metropolita Dionizy i wielokrotnie sami wierni (zabiegając nawet u premiera Rzeczypospolitej Walerego Sławka i prosząc dodatkowo o zasiłek na budowę). Obok próśb prawosławnych pojawiły się jednakże inne oferty zagospodarowania budulca. Magistrat miasta Nowego Dworu, a następnie wójt gminy Pomiechowo proponowali przeznaczenie świątyni na cele budowy kompleksu szkolnego, którego brak miał być silnie odczuwalny na administrowanych przez nich terenach ${ }^{56}$. Wśród wiernych krążyła natomiast pogłoska, że rząd planuje sprzedać ją Żydom ${ }^{57}$.

Władze ministerialne stały na stanowisku likwidacji świątyni, co w świetle prawa było możliwe ze względu na jej zagrażający bezpieczeństwu publicznemu stan techniczny ${ }^{58}$. Przychylnym okiem patrzyły na propozycję budowy szkół, gdyż zarówno w jednym, jak i w drugim wypadku lokalne samorządy podejmowały się spełnić postulaty prawosławnych. Przedmiotem sporu było jednak to, ile cegieł z rozebranej świątyni przeznaczyć na cele cerkiewne i jaką kwotą wesprzeć starania wiernych. Początkowo nawet zastawiano się, czy w ogóle wznosić nowy obiekt, czy wystarczające nie byłoby wyremontowanie dawnej plebanii, w której od przeszło dziesięciu lat mieściła się domowa cerkiew. Takie działanie generowało mniejsze koszty, a dodatkowo pozwalało oddać w dzierżawę (wraz z innymi ziemiami cerkiewnymi) działkę, na której dotychczas mieściła się cerkiew św. Aleksandry.

Na podstawie zachowanych źródeł można wskazać, że do ostatecznego rozwiązania sprawy doszło 12 września 1933 roku. W tym dniu w Warszawie spotkali się przedstawiciele władz samorządowych, hierarchii cerkiewnej i stanisławowskiej parafii. Tę ostatnią reprezentowali ksiądz J. Sajczuk, Aleksy Fedorow, Aleksy

\footnotetext{
${ }^{54}$ A. Troc-Sosna, G. Sosna, Hierarchia i kler Kościoła..., s. 746.

55 AAN, MWRiOP, sygn. 1208, s. 30.

56 Tamże, s. 75, 110.

57 Tamże, s. 67-68.

58 P. Zubowski, Cerkwie prawostawne..., s. 48-49.
} 
Kuzniecow i Kimon Wierbicki. Porozumienie między stronami brzmiało jak następuje:

Wydział Powiatowy Sejmiku Warszawskiego po dokonaniu rozbiórki gmachu cerkwi pozostawi na placu dla potrzeb budowy nowego domu modlitwy we wsi Stanisławowo 45.000 sztuk cegły, oraz 4 filary wewnętrzne cerkwi nierozebranemi do wysokości $6.00 \mathrm{mtr}$. W wypadku zaś, jeśli przy rozbiórce zostanie uzyskana większa ilość cegły aniżeli 450.000 sztuk Wydział Powiatowy obowiązany będzie pozostawić na placu $10 \%$ tej cegły /z ilości ponad 450.000 sztuk/ i 5\% połówek. Niezależnie od powyższego Wydział Powiatowy zobowiązuje się pozostawić na miejscu do dyspozycji Władz Parafjalnych następujące przedmioty i materiały: 1/ stopnie wejściowe żelazne, 2/ tambury wewnętrzne, 3/ płyty terakotowe z głównego ołtarza, 4/ asfaltową podłogę, 5/ urządzenia cerkiewne, jak to: ikonostas, szafy, balustradę, krzyże z kopuł i 2 kopułki małe w całości /o ile to będzie możliwe/, 6/ okna i drzwi, $7 / 5 \mathrm{~m}^{3}$ drzewa z rozbiórki wiązań, 8/ 50 ark. blachy z pokrycia dachowego, 9/ schody drewniane na dzwonnicę. Wydział Powiatowy dostarczy również parafji projekt domu modlitwy do zatwierdzenia, oraz będzie sprawował przez wyznaczone przez siebie osoby fachowe nadzór techniczny przy budowie ${ }^{59}$.

Większość materiału z rozbiórki dawnej świątyni przeznaczono na wzniesienie gmachów szkolnych w Pomiechówku. Według informacji zebranych przez K. Sielicką-Baryłkę za taką decyzją optował sam były minister spraw wewnętrznych, a wkrótce premier gen. Felicjan Sławoj-Składkowski. Wraz z żoną Germaine Susanne Coillot zaangażował się w działalność społeczną na terenie Pomiechówka, organizując m.in. kolonie letnie dla dzieci i przyczyniając się do budowy lokalnej drogi. Podobno miał osobiście, swoim samochodem ciężarowym, zwozić cegły na plac budowy ${ }^{60}$.

Być może zasługą Składkowskiego była również zgoda, którą dowództwo twierdzy w Modlinie wydało na rozbiórkę cmentarnej cerkwi Bogurodzicy Pocieszycielki Strapionych. Jak pisano, były to nieprzedstawiające żadnej wartości ruiny, z których można było pozyskać do 12 tysięcy sztuk cegły ${ }^{61}$.

Postanowiono, że nowa świątynia zostanie wzniesiona na miejscu dawnej cerkwi św. Aleksandry. Projekt inż. arch. Bogdana Lewandowskiego przewidywał jednak obiekt przeszło cztery razy mniejszy i o znacznie skromniejszej dekoracji. Zdecydowanie zmienił się również sposób przekrycia bryły. Sporych rozmiarów kopułę i cztery flankujące ją hełmy zastąpił wysoki namiotowy dach zwieńczony niewielkim cebulastym hełmem. Zastosowanie takich form stylistycznych nie mówiło już nic o misji, którą wyznaczono kolonistom przed blisko stu laty. Zrywało z monumentalizmem, a także z jednoznacznymi skojarzeniami z tradycyjną dla Imperium Rosyjskiego architekturą sakralną.

Umowa pomiędzy prawosławnymi a władzami wojewódzkimi tych pierwszych obarczała kosztami, które należało ponieść przy wzniesieniu nowej cerkwi.

${ }^{59}$ AAN, MWRiOP, sygn.1208, s. 139-140.

${ }^{60}$ K. Sielicka-Baryłka, Ślad estoński..., s. 36-40; P. Oleńczak, Gen. Felicjan Stawoj Składkowski. Dobrodziej Pomiechówka, „Gazeta Pomiechowska. Biuletyn Informacyjny Gminy Pomiechówek" 2012, nr 3 (53), s. 10.

${ }^{61}$ AAN, MWRiOP, sygn.1208, s. 136-138. 
Najpewniej była to jedna z przyczyn, dla której podjęte prace budowlane zostały ukończone dopiero w roku 1938 (w podobnym czasie trwała budowa szkoły w Pomiechówku). Kłopoty finansowe mogły być też powodem niewzniesienia dzwonnicy, którą miał zakładać projekt Lewandowskiego (poprzednia została rozebrana) ${ }^{62}$. Mimo wcześniejszych postulatów zburzenia dawnego domu parafialnego i budowy na jego miejscu nowego obiektu, co najmniej do lat sześćdziesiątych służył on jako mieszkanie dla proboszcza i jego rodziny ${ }^{63}$.

Piotr Rajecki podaje, że w roku 1992 podczas remontu świątyni odkryto w schowku duży zbiór ikon. Trudno powiedzieć, dlaczego nie zabezpieczono ich podczas prac rozbiórkowych w latach trzydziestych. Podobnie zagadką pozostaje los utensylii cerkiewnych oraz wyposażenia świątyni. Najpewniej w trakcie robót uległy zniszczeniu. Do Stanisławowa przeniesiono bowiem ikonostas, a także niezbędne sprzęty liturgiczne z dawnego soboru św. Jerzego w Modlinie, który władze wojskowe zaadaptowały na garnizonowy kościół katolicki św. Barbary ${ }^{64}$.

\begin{abstract}
$* * *$
Widok powoli niszczącej się naszej rodzinnej świątyni okropnie nas, okoliczną ludność prawosławną Stanisławowa, jako centrum i pięciu sąsiednich wiosek, męczy, gdyż więcej niż 15 lat odczuwamy brak domu modlitwy, gdyż więcej niż 10 lat staramy się o kaplicę... I nikt nie odpowiada na nasze błagania... Dla kogo taki stan rzeczy jest korzystny, nie wiemy... A jednak uczucie nasze religijne ciągle cierpi i jest dotknięte... ${ }^{65}$
\end{abstract}

Słowa te, choć stanowią pewne powtórzenie przedstawionych powyżej kwestii, wydają się dobrze oddawać charakter wskazanego w tytule niniejszego artykułu okresu dwudziestu lat, w którym przyszło żyć wiernym stanisławowskiej parafii. Determinacja i upór, pomimo utraty wszystkiego, co konstytuowało tę niewielką społeczność, doprowadziły do budowy nowej świątyni. Było to zjawisko wyjątkowe w kontekście sukcesywnych likwidacji i rozbiórek rosyjskich cerkwi zarówno na terenie samej Warszawy, jak i całego Mazowsza ${ }^{66}$. Tym bardziej że w czasie, kiedy ukończono prace budowlane przy cerkwi, w innej części byłego rosyjskiego zaboru,

${ }^{62}$ P. Rajecki, Parafia św. męczennicy..., s. 179.

${ }_{63}$ K. Sielicka-Baryłka, Ślad estoński..., s. 52.

${ }^{64}$ R. Gołąb, Ilustrowana monografia miasta..., s. 608.

${ }^{65}$ AAN, MWRiOP, sygn. 1208, s. 67.

${ }^{66}$ Zob. m.in. P. Paszkiewicz, Pod bertem Romanowów..., s. 188-201; H. Sienkiewicz, Cerkwie w krainie kościołów, Warszawa 2006, s. 147-177; P. Zubowski, ,...wrzeszcza w środku miasta: patrzaj na mnie!". Zmiany w przestrzeni urbanistycznej miast centralnych województw II Rzeczypospolitej w związku z likwidacją cerkwi prawosławnych [w:] I. Barańska, M. Górzyński (red.), Odbudowy i modernizacje miast historycznych w Europie pierwszej połowy dwudziestego wieku. Naród, polityka, spoleczeństwo, Kalisz 2016, s. 204-227. 
na Lubelszczyźnie, doszło do masowej akcji burzenia nieczynnych prawosławnych świątyń ${ }^{67}$.

Podobnie jak ćwierć wieku wcześniej, cerkiew św. Aleksandry uległa zniszczeniu w trakcie II wojny światowej. Ten fakt, jak i zmniejszenie się liczby wiernych, którzy wyjechali na stałe do Związku Radzieckiego, przyczyniły się do zamknięcia świątyni na kolejne dziesięciolecia. Wysiłki podjęte przez warszawską hierarchię cerkiewną oraz najpewniej pozostałą grupę parafian doprowadziły do jej ponownego otwarcia i przydzielenia stałego duchownego. Wielką szansą dla cerkwi stała się budowa z końcem lat siedemdziesiątych XX wieku Prawosławnego Domu Opieki Społecznej „Betania”. Jego funkcjonowanie zwiastowało zarówno zasilenie parafii przez nową, liczną grupę wiernych, jak i fundusze na renowację świątyni. Gruntowny remont w latach 2013-2016, polegający m.in. na pozłoceniu dachu i nasadzeniu na niego pięciu nowych hełmów z wysokimi prawosławnymi krzyżami, sprawił też, że jej skromna szata architektoniczna stała się dużo bardziej reprezentacyjna.

Współcześnie cerkiew św. Aleksandry jest jednym z wielu wyznaczników wielokulturowego i wielowyznaniowego Mazowsza. Od kilku dziesięcioleci objęta jest ścisłą państwową ochroną konserwatorską ${ }^{68}$. Przy tym nie traktuje się jej jako pomnika czy narzędzia rusyfikacji, a raczej jako świadectwo i zabytek trudnej polskiej przeszłości, a przez to integralny element polskiego krajobrazu kulturowego, który warto zachować dla kolejnych pokoleń zarówno ze względu na prawosławną społeczność okolic Warszawy, jak i ogół społeczeństwa.

\section{Bibliografia}

\section{Archiwalia:}

Archiwum Główne Akt Dawnych, Zbiór kartograficzny: sygn. 199-19, Plan der neuangelegten Colonie bei Modlin im Amte Zakroczym copirt durch Linke, bd. sygn. 324-101, Plan sytuacyjny Kolonii Aleksandryjskiej, 1840 sygn. 334-71, Pravoslavnaâ Cerkov v Aleksandrinskoj kolonii, 1840

${ }^{67}$ G. Kuprianowicz (red.), Akcja burzenia cerkwi prawosławnych na Chetmszczyźnie i Potudniowym Podlasiu w 1938 roku - uwarunkowania, przebieg, konsekwencje, Chełm 2009. Inne, interesujące spojrzenie przedstawia m.in. J. Kęsik. Zob. tegoż, Udziat wojska w akcji rewindykacyjno-polonizacyjnej we wschodnich i poludniowych powiatach województwa lubelskiego w latach 1937-1939, „Kwartalnik Historyczny” 2014, R. CXXI, z. 4, s. 799-831; tegoż, Zanim zburzono cerkwie. Z dziejów prawosławia na Chetmszczyźnie i Podlasiu Poludniowym w latach 1918-1937 [w:] I. Hofman (red.), Ukraiński polonofil. Pamięci Bohdana Osadczuka, Lublin 2012, s. 129-160.

${ }_{68}$ Do rejestru zabytków nieruchomych cerkiew została wpisana 12 kwietnia 1962 r., pod numerem 1106/677/62, http://www.nid.pl/p1/Informacje_ogolne/Zabytki_w_Polsce/rejestr-zabytkow/zestawienia-zabytkow-nieruchomych/stan\%20na\%2030.09.2016/MAZ-woj.-rej.pdf [odczyt: 24.10.2016]. 
Archiwum Akt Nowych, Ministerstwo Wyznań Religijnych i Oświecenia Publicznego:

sygn. 1060, Referat Wyznania Prawosławnego. Parafie i filie: erekcja, kasata, siedziba, delimitacje, przyznawanie etatów - sprawy szczegółowe, t. IX, lit. P

sygn. 1208, Majątki - cerkwie prawosławne - akta szczegółowe w układzie alfabetycznym wg miejscowości, lit. A

\section{Literatura:}

Cynalewska-Kuczma P., Architektura cerkiewna Królestwa Polskiego narzędziem integracji z Imperium Rosyjskim, Poznań 2004.

Delnicki A., W sprawie cerkwi, „Dziennik Narodowy”, 1.02.1919, R. V, nr 26.

Korženevskij I., Kratkaâ istoriâ Cholmsko-Varšavskoj eparhii. Sostoânie varšavskoj eparhii pod upravleniem preosv. Nikanora, „CHVEV”, G. II, n. 22, 15 (27) noâbra 1878, s. 6-14.

Kozlovskij R., Pravoslavnyj prihod v Stanislavove, „Cerkovnyj Vestnik”, maj-iûn 1971, s. 22-24.

Lotockij A., Cerkovno-istoričeskoe i statičeskoe opisanie Varšavskoj Pravoslavnoj Eparhii. Sostavennoe v 1853 g. Klûčarem Varšavskago kafedral'nago sobora, Počaev 1863.

Oleńczak P., Gen. Felicjan Sławoj Składkowski. Dobrodziej Pomiechówka, „Gazeta Pomiechowska. Biuletyn Informacyjny Gminy Pomiechówek” 2012, nr 3 (53).

Papierzyńska-Turek M., Między tradycją, a rzeczywistością. Państwo wobec prawosławia 1918 1939, Warszawa 1989.

Paszkiewicz P., Pod berłem Romanowów. Sztuka rosyjska w Warszawie 1815-1915, Warszawa 1991.

Paszkiewicz P., W stużbie Imperium Rosyjskiego 1721-1917. Funkcje i treści ideowe rosyjskiej architektury sakralnej na zachodnich rubiezach Cesarstwa i poza jego granicami, Warszawa 1999.

Rajecki P., Parafia św. męczennicy Aleksandry w Stanisławowie koło Pomiechówka, „Kalendarz Prawosławny" 2006, s. 175-182.

Sielicka-Baryłka K., Ślad estoński na Mazowszu - prawosławna parafia w Stanisławowie, praca magisterska napisana pod kierunkiem dr. hab. J. Wasilewskiego w Instytucie Etnologii i Antropologii Kulturowej Uniwersytetu Warszawskiego, Warszawa 2003.

Sokoł K., Sosna A., Cerkwie w centralnej Polsce 1815-1915, Białystok 2011.

Sosna G., Troc-Sosna A., Hierarchia i kler Kościoła prawosławnego w granicach II Rzeczypospolitej i Polski powojennej w XIX-XXI wieku, Ryboły 2012.

Szczerbatow A., Rządy księcia Paskiewicza w Królestwie Polskim (1832-1847), Warszawa 1900.

Torskij V., Aleksandrinskij pravoslavnyj prihod i hram v russkih koloniâh Varšavskoj gubernii, „CHVEV”, G. XX, n. 15, 1 (13) avgusta 1896, s. 277-279.

Woźniak A., Kartki z dziejów prawosławnej parafii św. Aleksandry w Stanisławowie koło Modlina, „Etnografia Polska” 2001, t. 45, z. 1-2, s. 183-194.

Zubowski P., Cerkwie prawosławne Łodzi i regionu łódzkiego w dwudziestoleciu międzywojennym (1918-1939), Białystok 2014. 